\title{
Introduction
}

\section{THE VIRTUE OF ONE VINEYARD: Jewish Refuge Reconsidered}

\author{
Solomon had a vineyard, \\ He let others guard it... \\ My vineyard stands before me. \\ You Solomon, keep your thousands.
}

Shir Ha'Shirim 8:11-12

\begin{abstract}
ach story of refuge with dignity is worth telling. Each has a different - melody, a different message. Once Chaya Leah Walkin's story found me, I knew that I was obliged to convey its undertones in a way that sets it apart from many other narratives of survival during the Shoah. Through the writing of this book, I became the guardian of a unique vineyard, unlike the "thousands" that the Song of Songs-Shir Ha'Shirim - attributes to King Solomon. He owned many fields and could afford to allow others to watch over them. For me, the act of listening to one particular voice in the fullness of its emotional and historical details transformed yet another Holocaust remembrance into a life-nourishing garden from which, I hope, others may draw nourishment as well.

Judith Miller had already pioneered this narrative strategy as early as 1990 in a book entitled: One by One: Facing the Holocaust. In this work, Miller sought to counter the dullness of the past that accosts us when we survey the huge field of atrocities in the twentieth century. The best antidote against the urge to either summarize or deny the lessons of the Shoah is to rescue singular fragments one story at a time:
\end{abstract}

Abstraction is memory's most ardent enemy. It kills because it encourages distance, often indifference. We must remind ourselves that the Holocaust 
xvi | Introduction

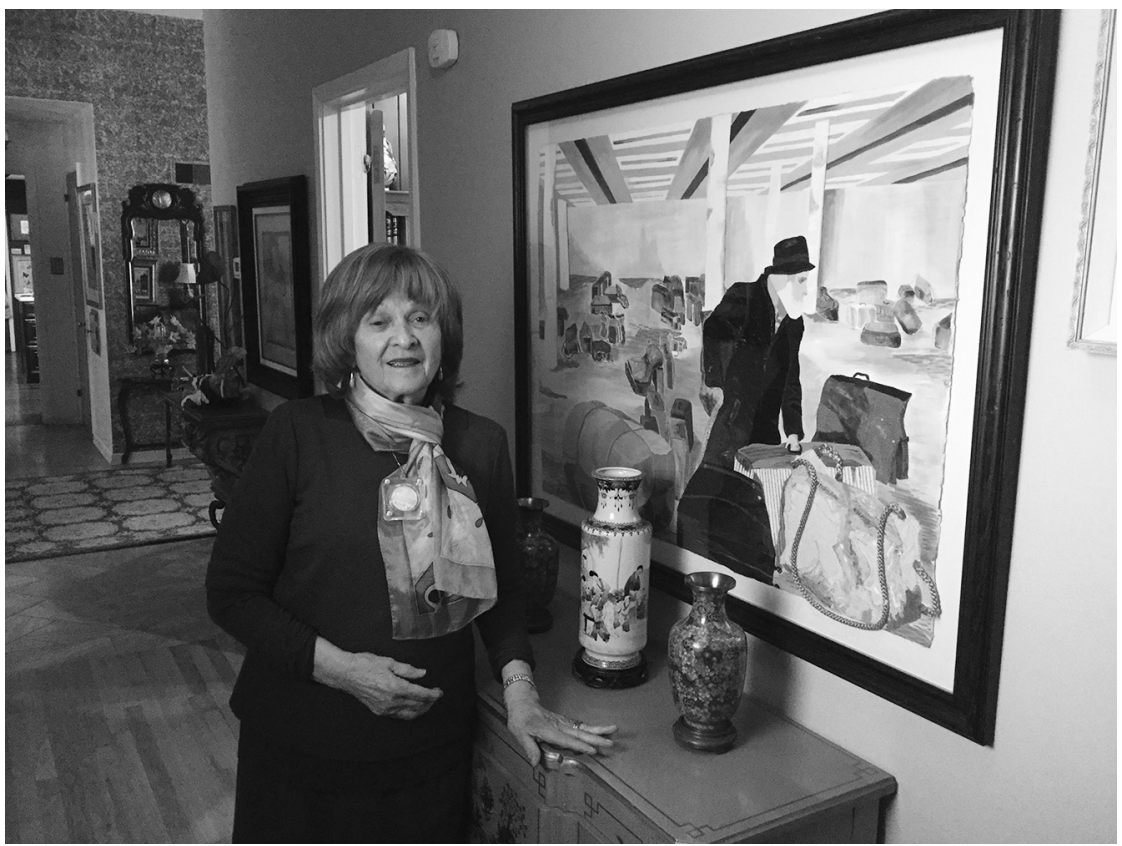

Rebbetzin Chaya Leah Small in her home in Chicago with collage of Jewish refugee.

was not six million. It was one plus one, plus one... (Only thus) is the incomprehensible given meaning. ${ }^{1}$

Judith Miller's project honored the singularity of the dead and challenged other scholars to similarly vivify the lives of those who survived atrocity.

Deborah Dwork and Robert Jan Van Pelt embraced this challenge as well in their study, Flight from the Reich: Refugee Jews 1933-1946. ${ }^{2}$ Published in 2012, this work combined documentary evidence with personal accounts to paint a more vivid portrait of various pathways of refuge out of Europe during the Shoah. Fleeing, as Chaya Leah Walkin's journey shows, did not evict one from the Holocaust experience. Rather, it shifted the locale, embedding Jews into geographies and temporalities that were unfamiliar and often terrifying.

1 Judith Miller, One by One by One: Facing the Holocaust (New York: Simon and Shuster, 1990), 123.

2 Deborah Dwork and Robert Jan van Pelt, Flight from the Reich: Refugee Jews 1933-1946 (New York: W. W. Norton, 2012). 
It was flight itself that tested the innermost resources of Jewish life in a world gone mad. What did refugees carry with them to survive with dignity? In Chaya Leah's Chicago home, I found a piece of artwork that sharpened this question in my mind. It is a collage hanging in a hallway quite apart for the many lovely Chinese vases and cloisonné-decorated cabinets that recall Chaya Leah's childhood in Shanghai.

This work centers upon an aged man in a black coat and hat, walking stick in hand, grasping a roped-up suitcase. Old-fashioned bags and trunks are strewn all about him. A dismantled room looms in the background. The white bearded figure does not look back at all that loss and destruction. He has grasped only what he can carry with fierce determination. He will move on.

At first, I only noticed the haunted gaze. This does not seem to be the first time that the man-clearly a Jew — has been chased out of his home. Nor has he become inured to the pain of leaving precious bits of the familiar past behind. Yet, the more I looked at the collage the more I came to appreciate the moral strength it takes to select what to carry.

Even in a hurry, grab what is most precious, make a choice about which valuables go into that one suitcase, which values will keep you strongly Jewish in alien worlds. This is also the leitmotif of the Walkin family's refugee experience. It is a history-seasoned strategy for meaningful survival that stretches all the way to the Spanish Inquisition and, before that, to the Babylonian exile.

One could say that Jews became expert refugees by force of historical circumstance. But that is not quite the truth. There were innumerable small and large acts of choice that shaped survival, that lent it meaning beyond physical endurance. In Chinese, the term for raw tenacity—ren 忍—is comprised of an ideograph showing a knife over the human heart. Here, endurance requires one to submit to violence, to outwit its brutality by simply going on. Chaya Leah and her family did more than endure.

Reflecting upon the meanings of their Jewish survival, I found myself coming back to the philosophical meanings of "agency." This overused theoretical term does, nonetheless, capture something essential about Chaya Leah's journey. It highlights the autonomous resources within a person or community that facilitated survival with dignity in harsh times. Even as a small child, Chaya Leah Walkin understood that Jews were more than victims of a vicious fate. In the effort to understand this sense of an inner fulcrum 
xviii | Introduction

for action, I turned to the work of my Wesleyan colleague, historian Gary Shaw, who argues:

It is time for historians to show how attempts to understand the self are essential to historical work... For it is the agent in concert with others who is the one sure place where meaning gets made and unmade, and where history is waged and witnessed. ${ }^{3}$

Shaw, from his position as editor of History and Theory, dared to take issue with the various theoretical frameworks, including Marxism and Postmodernism, which took the agent out of history. He pointed out that the responsibility for making meaning out of the debris of the past remains compelling for each of us who writes history. We cannot shoulder this task without taking into account how individuals and groups fashion survival into something more than naked endurance.

Philosopher Emil Fackenheim, in contrast to Gary Shaw, tackled the question of endurance in light of his own experience as a survivor of the Sachsenhausen concentration camp. Decades before History and Theory debated the problem of agency, Fackenheim forced himself to look into the ashes of the Shoah and declared:

\begin{abstract}
A Jew endures because he is commanded to endure instead of going mad...
Whence has come our strength to endure, to affirm our Jewishness against the forces of hell itself? The question produces abiding wonder. It is a commanding Voice without which we would have perished in our affliction. ${ }^{4}$
\end{abstract}

This "voice" can be heard in Chaya Leah's jottings about China and Japan as well. These places allowed Jews to outwit the madness that engulfed Europe during the Holocaust. The voice described by Fackenheim was also audible in Kobe as well as in Shanghai. It echoed forward in time and continued to strengthen Jewish identity after the war.

\title{
BUT DO WE LEARN FROM HISTORY?
}

For Fackenheim, the voice commanding endurance emanated from Auschwitz and had to be heeded as an additional commandment beyond the 613 that

3 Gary Shaw, "Agency and Language in the Postmodern Age," History and Theory (December, 2001): 1-9.

4 Emil Fackenheim, God's Presence in History: Jewish Affirmations and Philosophical Reflections (New York: Jason Aronson Inc., 1970), 182. 
form the core of traditional Judaism. For Chaya Leah, survival with Jewish dignity was an essential outgrowth of the Torah itself and of the distinguished legacy of Talmudic scholarship that had shaped the life of her parents before they became stateless refugees.

Born in 1916 in Halle (Germany), Emil Ludwig Fackenheim was a Western-educated intellectual in his 20s when he was arrested during Kristallnacht. Chaya Leah, by contrast, was merely a child of five when she had to hide in a wagon to escape the murderous hatred of Jews raging in Europe. Her expression for the Holocaust-Churb'n-draws upon an older, more traditional lexicon than Fackenheim's philosophical reflections about Auschwitz.

This Yiddish term builds upon the Hebrew term for "destruction" associated with the ravage of the First and Second Temples in Jerusalem. Churban, which connotes a fiery ruination, also calls to mind the biblical concept korban used to describe the sacrificial burnt-offerings that sanctify both God and the Jewish people. By the late 1940s, the expression Churban Eyrope was on the lips of most Yiddish-speaking survivors who sought to fathom the destruction of the world that they had left behind. Looking back at her own family's survival, Chaya Leah marveled at the legacy of scholarship that had carried Jewish life forward from the ashes of the Holocaust:

The churban destroyed all the yeshivas, yet the Mir is the only Yeshiva that was saved whole, as after the second churban, Yavne remained whole.

And we see what followed as history repeats itself.

The Mir in Shanghai was saved as a whole and look at what they accomplished, and the blooms of their work.

History repeats itself.

But do we learn from history?

Here, Chaya Leah is paying tribute to the extraordinary renewal of Torah learning that followed the survival of the Mirrer Yeshiva in Shanghai during the war. Her own family's links to the yeshiva are discussed at length in this book. For now, it is important to see how Chaya Leah placed her own experience as a refugee in the larger context of Jewish history going back to the destruction of the Second Temple in $70 \mathrm{CE}$.

Her reference to Yavne is no accident. It shows a conscious continuation of the legacy of Rabbi Yochanan Ben Zakkai (30-90 BCE), who (according to the Babylonian Talmud) asked Vespasian, the emperor of Rome: "Give me Yavne and its sages." Ben Zakkai was not immune to the horror and pain that 
$\mathbf{x x} \mid$ Introduction

beset Jerusalem after the destruction of the Temple. Yet, he also understood that continuing Torah scholarship in the hamlet of Yavne would ensure Jewish survival despite this catastrophic loss. Chaya Leah looks back and sees both Yavne and the Mirrer Yeshiva as beacons of hope, as sources of spiritual flourishing for the Jewish people as a whole.

At the same time, her scorching question stands: "But do we learn from history?" This question rang loudly in my mind as I was working on this book. Looking around the world today, I saw very few signs that we have learned enduring lessons from Churban Eyrope. I think back to Max Kaufmann's heartrending work entitled Churban Lettland (The Destruction of the Jews of Latvia $)^{5}$ published in 1947 and realize that the twenty-first century continues to besmirch the memory of Jews murdered during the Holocaust. As recently as May 2016, a major memorial to the Lithuanian Shoah was vandalized in honor of Adolf Hitler's birthday. News flashes of Jewish names defaced with swastikas deepen for me the searing doubt in Chaya Leah's question: "But do we learn from history?"

I have no answer, but I do know that there is a terrifying moral and historical myopia afoot in the world today. Wanton cruelty reigns undiminished after the Holocaust. Hatred and murder of Jews, alas, has not become a matter of past history. So Chaya Leah's question and Emil Fackenheim's injunction about endurance have lost none of their bitter force. One way that this book addresses ongoing madness in the global context is by detailing the inner resources that enabled refugees to survive with dignity. Restoring "agency" to victims of hatred helps us, quite literally, to see them and ourselves in a fresh light.

The urgency of this task became apparent to me as I looked at a loudly publicized art exhibition entitled "Love Without Boundaries-Jewish Refugees in Shanghai." First opened in China in 2011, the exhibition also arrived with diplomatic fanfare to the International Convention Center of Jerusalem on May 10, 2015. The show revolved around forty oil paintings depicting various aspects of Jewish life during the war in China. Here was a glossy, sentimentalized version of Jewish survival that veered toward historical distortion again and again.

Official commemorations in Jerusalem, as in Shanghai, often depict child survivors in Shanghai as helpless beneficiaries of Chinese benevolence. One of the paintings in the exhibition that evoked this falsified pathos was

5 Max Kaufmann Churbn Lettland: The Destruction of the Jews of Latvia, ed. Gertrude Schneider and Erhad Roy Wiehn (Kostanz, Germany: Hartung-Gorre, 2010). 
entitled "True Emotion Breaks the Blockade." This work showed Jews behind barbed wires-something that never happened in Shanghai. The text that accompanied the painting embroidered an agency-denying narrative in the following terms:

The Japanese authorities did not want to slaughter Jewish refugees directly. Instead they isolated the Jews, restricted their freedom and persecuted them. Once the Japanese authorities kept more than 2000 Jews in an area and cut down all power and water supplies in order to starve them to death. In the hard times, caged in the Ghetto, true emotion (sic) break the blockade. The kind Shanghai residents and some charity organization could not see them suffering from starvation. So they discreetly sent food and water to these Jews. In this way, the Jews behind the layers of metal fences could barely survive.

Chaya Leah was never one of the hungry girls receiving a handout behind barbed wire, even though some features of her childish face are recognizable in the painting. In fact, there were no such Jewish children in Shanghai during the war.

By trying to augment retrospectively China's role in the rescue of Jewish refugees, the painting portrayed a lie. The role of Japanese authorities in actually saving Jewish lives is an inconvenient truth that continues to be ignored on the Chinese mainland and denied in the painting.

Another aspect of the Jewish refuge in Shanghai during the Shoah that is literally being painted over here is the social and cultural distance between Chinese and Jews. In Chaya Leah's recollections, as well as in the writings of many other survivors, we learn that contacts between Jewish refugees and ordinary Chinese were rare and made awkward by language and religious barriers. "Love Without Borders," by contrast, emphasized the ties between charity-minded Chinese and helpless Jews. In the process, it robbed the refugees of their own agency by portraying them as victims of a cruel fate ameliorated by China's kindness.

In fact, the various Jewish communities in China had numerous cultural, spiritual, and financial resources to ensure survival with dignity. The Jerusalem exhibit, much like the one in the Shanghai Jewish Refugees Museum, which opened in 2007, diminishes this aspect of history. Survivors of that period, most notably Dr. Lotte Lustig Marcus, have been publicly critical of these distorted, politically self-serving depictions of Jewish survival. ${ }^{6}$

6 Marcus, Lustig Lotte. "Contradicting Revisionist History." Points East 29, no. 1 (March, 2014): $1-3$. 
xxii | Introduction

How to give voice to the agency that was accessed by Jewish survivors in China became one of the core challenges of this book. Digging beneath the "painted history" being currently produced was the first step in meeting that challenge. A more difficult narrative task awaited me as I sought to convey Chaya Leah's distinctive cadence and vision, especially in a field dense with autobiographies and memoirs about Jewish refuge during the war.

The very multiplicity of personal and scholarly accounts enabled me, in the end, to listen more keenly to Chaya Leah's own voice. As Alphonso Lingis noted in his study called First Person Singular, "voice is a matter of slow paced, often traumatic embodiment."7 In Chaya Leah Walkin's embodied voice I heard the scars, hesitations, and hopes of a child who came of age in wartime China. References to Torah observance and to the distinguished Talmudic scholarship of the Walkin family peppered her recollection, and therefore also color my evocation of the unique timbre of Chaya Leah's voice.

This book, however, is not an act of ventriloquism. Chaya Leah Walkin does not speak through my voice. Instead, I have sought to create a different kind of middle ground between our disparate visions and versions of history. It was my decision, for example, to frame Chaya Leah's story with comparative reflections about history and trauma. After decades of recording the voices of Chinese intellectuals who survived the Cultural Revolution, I turned with a seasoned ear to the voice of the child who lived through the war in Shanghai. It was my choice to deepen the echoes between the child's voice and other survivors of historical trauma in order to augment the reader's understanding of why this narrative continues to matter in the twentieth-first century, many decades after the war ended in Shanghai in 1945.

\section{NOT A BOY NAMED 6881}

To enter Chaya Leah's world required me to carve a distinctive path through the thick forest of existing works about Jewish refuge in Shanghai. Chaya Leah herself was mindful of this large body of commemorative work, and wondered how one more account would add to or change the story of the Shoah. I told her that, in time, I would find the themes and the narrative strategy needed to make this book stand its own ground.

In the course of our collaboration, Chaya Leah sent me a volume of memoirs that had moved her deeply. It was written by Israel Starck and was entitled

7 Alphonso Lingis, First Person Singular (Evanston, IL: Northwestern University Press, 2007), 264. 
A Boy Named 68818. ${ }^{8}$ Here, a Torah-observant Jew born in 1929 retells his survival in the death camps to his daughter Miriam. The work is consciously crafted as an educational tool for students in Jewish day schools. Its goal is to guide young minds in fathoming both the horrors and the spiritual heroism possible during the Holocaust. With specially commissioned drawings, the book speaks about the commitment to observing mitzvoth in the toughest circumstances imaginable, including Auschwitz. After reading through this artfully crafted project, I told Chaya Leah: I am not going to write a work like A Boy Named 68818.

Yes, my subject was also a child, but she was not a survivor of the death camps. Chaya Leah's story led me to think more deeply about refuge across cultural landscapes that were far from the Torah world of Eastern Europe. Fathoming these journeys required an act of imagination that went beyond the trials of Auschwitz. The focus of this work is a very young woman and her experiences demanded attention to events beyond the war.

Early on in my conversations with Chaya Leah in Chicago, I thought of Margaret Mead's work, Coming of Age in Samoa. This anthropological study stands in sharp contrast to the book by Israel Starck. Published for the first time in 1928, it also appears at first glance to be far afield from the life of a girl raised in a prestigious rabbinical family. Yet, looking at photographs of Chaya Leah as a young teenager with budding breasts at the end of the war in Shanghai, I began to think differently.

Margaret Mead helped me look more carefully at the details that mark female lives without falling prey to the condescension palpable in subtitles such as: "A Psychological Study of Primitive Youth for Western Civilization." The happy and chatty natives who populate Mead's version of Samoa have no counterpart in Chaya Leah's world. Yet, those girls took on adult responsibilities much like Chaya had to in caring for, and later protecting, younger siblings. As Mead writes:

The chief nursemaid is usually a child of six or seven, who is not strong enough to lift a baby of 6 months old but can carry the child straddling the left hip. ${ }^{9}$

As a six-year-old, Chaya Leah had already become a refugee who crawled through winter snows into Lithuania with her terrified mother and two younger

8 Israel Starck, A Boy Named 68818 (New York: Feldheim Publishers, 2015).

9 Margaret Mead, Coming of Age in Samoa: A Psychological Study of Primitive Youth for Western Civilization (New York: William Morrow and Company, 1928), 128. 
xxiv | Introduction

siblings. By age seven, she had survived the scary journey from Vilna to Kobe in Japan. By the time she turned eight, Chaya Leah had also learned to bargain for food in the cacophonous alleys of Shanghai. All along, responsibility for younger siblings was clearly on her mind.

Turning from Kobe to Shanghai, I found no shortage of childhood memoirs written by women and men alike. Each tells a snippet of the refugee experience as seen through the eyes of displaced families, mostly from Germany and Austria. Too numerous to list here, I want to mention only those that shaped my own understanding of what was unique in Chaya Leah's experience as a girl embedded in the small Torah-observant community that had traveled together from Lithuania to China.

Among the many female voices that can be found in Shanghai memoirs, Vivian Kaplan's Ten Green Bottles captures most vividly a young woman's pre-war exploits in Vienna before being thrown into the maelstrom of war-torn Shanghai. Margaret Blair's Gudao: The Lone Islet is more firmly anchored on the Chinese terrain, with startling details about the Japanese occupation of the International Settlement as well as the internment camps where British citizens suffered deprivations and fear. ${ }^{10}$ These terrors also loomed over Chaya Leah's world on Liaoyang Road.

Both Vivian Kaplan and Margaret Blair were older and more secular than Chaya Leah Walkin. This holds true also for the male voices recorded in refugee memoirs, such as that of Sigmund Tobias, entitled Strange Haven: A Jewish Childhood in Wartime Shanghai ${ }^{11}$ and Samuel Iwry's To Wear the Dust of War. ${ }^{12}$ Both Tobias and Iwry shared some of Chaya Leah Walkin's background. Both men had been on the margins of the yeshiva world in China.

Sigmund Tobias, born to Polish Jews in 1932, had spent his early childhood in Berlin. He came to China with the wave of German Jewish refugees and ended up briefly at the Mirrer Yeshiva in Shanghai. As he wrote in his memoir, this school offered more food and money, but the rigors of learning proved too daunting.

Samuel Iwry was born in 1910 into a religious family in Ukraine and had received the best Talmudic education available to young men of his generation. Long before his arrival in Kobe in March 1941, Iwry had embraced a secular

10 Margaret Blair, Gudao: The Lone Islet: The War Years in Shanghai-A Childhood Memoir (Bloomington, IN: Trafford Publishing, 2009).

11 Sigmund Tobias, Strange Haven: A Jewish Childhood in Wartime Shanghai (Champaign, IL: University of Illinois Press, 1999).

12 Samuel Iwry, To Wear the Dust of War: From Bialystock to Shanghai, to the Promised Landan Oral History (New York: Palgrave, 2004). 
intellectual climate strongly colored by Zionist beliefs. In Japan and in China, Iwry focused on Jewish emigration to Palestine. Yet, when the end of the war came, it was Chaya Leah's father, Rabbi Shmuel David Walkin, who helped Iwry to come to the United States. With a starting job teaching basic principles of Judaism to Jewish students Iwry went on to become America's foremost academic researcher on the Dead Sea Scrolls.

Kaplan, Blair, Tobias, and Iwry (along with dozens of other Jews who survived the war in Shanghai) penned memoirs focused on their brief China years in order to honor those who had perished in the Shoah. This work about Chaya Leah Walkin, by contrast, is neither a memoir nor a narrative focused solely upon the China years. Although I am a sinologist by training and have written previously about the Jewish communities in Shanghai during the war, I wanted to create here a broader canvas.

As a result, this narrative follows the broad outlines of Chaya Leah's life, from her birth in 1934 near Pinsk to the building up of a Torah community in Chicago. Through this broader time frame, I aim to capture the voice of the child who became a seasoned survivor as well as a highly respected community leader after the war.

With this more complex portrait consciously in mind, I reconstructed various fragments of Jewish as well as world history. By combining Chaya Leah's story with that of a world riddled by atrocity and moral myopia, I was able to discover the inner art of a distinctively Jewish refuge that went beyond survival in China. This effort to contextualize the experience of one particular refugee was greatly informed by existing academic scholarship on the Jewish experience in Shanghai. In recreating Chaya Leah's worlds, I drew much information from David Kranzler's path-breaking work entitled Nazis and Jews: The Jewish Refugee Community of Shanghai 1938-1945. ${ }^{13}$ This early book has now been augmented by critical studies authored by Marcia Ristaino, ${ }^{14}$ Steve Hochstadt, ${ }^{15}$ Maisie Meyer, ${ }^{16}$ and Gao Bei, ${ }^{17}$ just to mention those that

13 David Kranzler, Japanese, Nazis \& Jews: The Jewish Refugee Community of Shanghai, 19381945 (New York: Yeshiva University Press, 1976).

14 Marcia Ristaino, Port of Last Resort: The Diaspora Communities of Shanghai (Stanford, CA: Stanford University Press, 2003).

15 Steve Hochstadt, Exodus to Shanghai: Stories of Escape from the Third Reich (New York: Palgrave, 2012).

16 Maisie J. Meyer, Shanghai's Baghdadi Jews: A Collection of Biographical Reflections (London: Blacksmith Books, 2015).

17 Gao Bei. Shanghai Sanctuary: Chinese and Japanese Policies toward European Jewish Refugees during World War II (Oxford: Oxford University Press, 2013). 
xxvi | Introduction

I consulted most frequently. My own approach to Jewish survivors in China also draws extensively upon the research of Irene Eber, especially her collection of original sources entitled Voices from Shanghai: Jewish Exiles in Wartime China. $^{18}$

In discussing the rescue of rabbinical leadership during the war, I drew upon Ephraim Zuroff's well-documented study: The Response of Orthodox Jewry in the United States to the Holocaust. ${ }^{19}$ This book focuses upon the Vaad ha-Hatzala Rescue Committee, which was instrumental in aiding Chaya Leah and her family. In fact, there is evidence that Rabbi Shmuel David Walkin was one of the people who helped to distribute funds among the refugees in Shanghai, along with chief Rabbi Meir Ashkenazi.

The funds for this organization had been raised with great urgency and self-sacrifice in the United States during the Shoah. Responses to Zuroff's work have been both appreciative and highly contentious. No one challenges his scrupulous inquiry into the original documentation of the Vaad ha-Hatzala archives, which provides for the first time a clear chronology of the fundraising initiated by American rabbis at a time when the US government was doing very little to help victims of the Holocaust.

Questions raised by David Kranzler and Jonathan Rosenblum ${ }^{20}$ (among others) center upon Zuroff's critique of the "particularism" of this rescue operation. Was rescuing Torah scholars the only goal of the Vaad ha-Hatzala's exceptionally committed efforts? Did the funds that managed to reach Shanghai provide dignified survival solely for orthodox Jews, such as Chaya Leah's father and the students of the Mirrer Yeshiva?

Without entering into the details of this controversy, I am hoping that this narrative of Chaya Leah's life will cast new light upon these questions and thereby illuminate the inner landscape of Jewish survivors. The time is ripe now, I believe, to look more deeply into how Shanghai as a locale that shaped the meaning of life for Chaya Leah's generation. On the simplest level, the Chinese word shang (上) connotes an upward direction that also suggests something elevated or worthy of respect. When coupled with the Hebrew and

18 Irene Eber, Voices from Shanghai: Jewish Exiles in Wartime China (Chicago: University of Chicago Press, 2008).

19 Efraim Zuroff, The Response of Orthodox Jewry in the United States to the Holocaust: The Activities of the Vaad Ha-Hatzala Rescue Committee 1939-1945 (New York: KTAV Publishing House, 2000).

20 Jonathan Rosenblum, "Anatomy of a Slander," The Jewish Observer, August, 2005. 
Yiddish term chai (יח), the name of this city can be seen as the site of an enlivened existence, one that depended both upon endurance and ethical agency.

Combined, 上י-Shang-chai-is more than a place in time. It becomes a pathway for understanding how Jews managed to shape history rather than being its victims. For the Walkin family, this sense of agency was deeply rooted in an abiding faith in Jewish destiny. The music of Talmudic learning never ceased in Chaya Leah's world, whether the place was Lukatch, Vilna, Kobe, or Shanghai.

Among the many sources that comprised this regimen of study were biblical texts admonishing Jews to set up cities of refuge. Long before the crisis of displaced persons overwhelmed Europe during the Shoah — and again in our own times of war and terrorism - we read about the commandment to establish cities of refuge in chapter 34 of Bamidbar (the Book of Numbers). In these verses, Moses is instructed to designate certain cities in the Land of Israel to which anyone may flee who kills a person accidentally.

Called irei miklat these cities are meant to protect the killer from the vengeance of blood relatives of the deceased. These places were meant to harbor only those who truly did not foresee the consequences of their actions.

With due respect to historical and cultural differences, these irei miklat may yet provide a new paradigm for thinking about refugees. In a recent essay entitled "Refugee Awareness," Rabbi Jacob E. Fine argues for the heightened relevance of ancient Jewish teachings in the wake of the wars in Iraq, Afghanistan, and Sudan. Using the Talmud's elaboration of the biblical injunction to build cities of refuge, Fine points out:

\begin{abstract}
A Jewish court is obligated to straighten the roads to the cities of refuge, to repair them and broaden them. They must remove all impediments and obstacles... bridges should be built (over all natural barriers) so as not to delay one who is fleeing. "Refuge, Refuge" was written at all crossroads so that the perpetrator of manslaughter should recognize the way and turn there." These teachings reflect something remarkable about the rabbinic attitude toward cities of refuge. The emphasis on the great width and sound condition of the roads leading to cities of refuge, coupled with the injunction to widely publicize the existence of such paths, illustrates the seriousness with which the rabbis approached this biblically mandated communal responsibility. ${ }^{21}$
\end{abstract}

21 Jacob E. Fine, "Refugee Awareness," My Jewish Learning, http://www.myjewishlearning. com/article/refugee-awareness/. Accessed August 13, 2017. 
xxviii | Introduction

When Chaya Leah's family was forced to flee their home in 1939, there were no clear signposts directing refugees to safety. Their pathways were torturous, filled with fear and uncertainty.

Every bit of kindness along the way was deemed a miracle of divine providence revealed through the hands of specific human beings. From an exit visa signed by Japanese consul Chiune Sugihara to the caring ministrations of a Chinese amah (a young country girl brought in to help with housekeeping chores), the Walkin family benefitted from the generosity of strangers. Yet, the meaning of life that they affirmed throughout their years of refuge was all their own. It is this act of conscious affirmation that became the central theme of my own book about Chaya Leah Walkin.

\section{IN THE CROOK OF THE ROCK}

There is a world of difference between being simply a refugee and crafting one's own destiny in an inhospitable world. Refugees are constantly at the mercy of others. They are uprooted, cast out, defined by labels pasted upon their documents, their faces, their souls. Chaya Leah's childhood was also marked and marred by such degradation. But neither she nor her family became what they were labeled - stateless persons simply drifting according to the whims of a world increasingly consumed by a crazed hatred of Jews. They remained deeply, fully Jewish. They also remained humane toward others, with powers of giving and nurturing that one would not have expected among the dispossessed.

Simcha Elberg, who was one of the younger Torah scholars in Shanghai, recalled this combination of despair and kindness in an essay that pays tribute to Chaya Leah's father, Rabbi Shmuel David Walkin. Entitled "An Ish Chesed Whose Hospitality Knew No Bounds," this work starts with the author's poignant recollection of terror and loneliness before the Walkin family responded to the pain of an orphaned Jewish youth:

When World War II broke out, we were forced to flee from our homes and cities and we became refugees. We roamed from one country to another and could not settle down anywhere. We arrived as temporary uninvited guests. As a refugee, I was dreadfully lonely and learned about the misery of a person living by himself as a person whom the Torah decreed had to live in a City of Refuge far from his father and mother, and far from friends to whom he could reveal the sorrow in his heart... One man substantially 
relieved my loneliness. Who was that noble character who strengthened me and infused me with hope, who always found the right word succor for my limbs with drops of solace and vitality? It was Rabbi and gaon Harav Shmuel Walkin, zt'l... The amazing hospitality he showed me gave me the feeling that I have found not only a devoted and faithful friend but a father figure." ${ }^{22}$

Here, a noted Torah scholar (who became the founder and editor of the journal Pardes after the war) looks back at himself as an orphan in Shanghai. Elberg recalls the loneliness of a homeless refugee as well as the exceptional humanness that shone forth from the Walkin family, especially Chaya Leah's father. The quest to understand the wellspring of such solace in times of darkness led time and again to the words of Shir Ha'Shirim, Solomon's poetic Song of Songs.

In this ancient love poem, I found a fount of metaphors that helped to illuminate my work as the interlocutor of Chaya Leah's story. Initially, I had not expected a narrative of Jewish survival to have such a fruitful dialogue with a series of songs focused upon the passionate relationship between a man and a woman - a relationship that, according to rabbinical commentaries, also mirrors the devotion between the Jewish people and the divine. Over time, however, I have found that the verses of this poem were uniquely well suited for every step in my writing about the Walkin family.

A passage in chapter 2 of Shir Ha'Shirim has been especially useful as I sought the main themes of this work. I have used it both as the title of the book and as the key to a pivotal chapter about Chaya Leah's life in Shanghai. Here are the verses in the masterful translation of Ariel and Chana Bloch: ${ }^{23}$

My dove in the crook of the rock,

In the hiding place of the steep,

Show me your visage,

Let me hear your voice.

"The crook of the rock" and "hiding place of the steep" convey the difficulties of surviving in the midst of hardship, the loneliness of being embedded in a foreign world. The Hebrew words in the last two lines were especially apt as I was redefining my own calling as a historian:

22 Simcha Elberg, "Hagaon Harav Shmuel Walkin zt"l," Hamodia (August 14, 2014 ), 1.

23 Chana Bloch and Ariel Bloch, The Song of Songs: A New Translation, Introduction and Commentary (New York, NY: Random House, 1995). 
xxx $\mid$ Introduction

harini et mareaich

hashemini et kolech.

show me your visage

I would like to hear your voice.

Here, the vulnerable dove is asked to show her face, to sound her call in times and places inimical to song.

I, too, had sought the face of history in Chaya Leah's narrative and found that it was the question of voice that accosted me. This question carried the sound of both anguish and hope and it demanded that I find words to convey its complexity.

On Chaya Leah's childhood-resident certificate in Shanghai there is a face, but no sound. A small girl gazes out seriously, frozen in time. Two English words- "Polish Refugee" - stick out amid rows of Chinese characters. The child's name on this fraying piece of paper is typed simply as C. Walkin, a diminished hint of the complex self, much like the thumbprint beneath the photograph, personal and utterly generic at the same time.

In other documents, the girl is called "Chaja" or at times more fully "Chaia Leah." Each different spelling reflects an awkward, official attempt to place this eldest sibling among the Walkin children in a box where she might stay for a while. The boxes changed, the names changed, none conveying the inner struggles that define meaningful survival. None of the documents labeling this refugee give a hint about the passionate engagement with the sources of Jewish learning that remained a lifeline in the Walkin family's darkest hours.

So, I kept turning to Shir Ha'Shirim in order to hear better the music of affection between Jews and their life-sustaining traditions. Rabbinical tradition teaches that the words of erotic intimacy between the "Dod" (the Lover) and the "Raya" (the Beloved) reflect the love affair between the Jewish people and their redeemer. Without limiting it to a single event in history, commentators suggest that Shir Ha'Shirim encompasses key moments in the exodus from Egypt, in the building of the First Temple, and in the Babylonian exile as well during the long dispersion that followed the destruction of the Second Temple.

The human lovers in the poem seek one another, like the Jewish people ceaselessly in quest of protection throughout their trials and tribulations. This description of an intensely intimate relationship was incorporated into the traditional cannon through the advocacy of Rabbi Akiva, a foremost teacher and 
martyr who lived in the early second century CE. The Mishna (in Yadaim 3:5) records a debate about the status of this erotic poem. None of the other rabbis of that period doubted the value of Shir Ha'Shirim. But few were ready to grant it sacred status.

Rabbi Akiva, who had lived through persecution and endured a horrifyingly cruel death, was able to summarize the fullness of light and hope in Shir Ha'Shirim as follows: "The entire Bible is holy. But the Song of Songs is the Holy of Holies." It was in this most exalted chamber of Jewish learning that I found fresh words to reimagine Jewish survival during the Shoah.

Far from being a passive victim of fate, the Raya in Shir $\mathrm{Ha}^{\prime}$ Shirim is a strong-willed young woman who is confident in her quest for the Lover's ardor and protection. She called to mind Chaya Leah and her descriptions of a community that managed to affirm its humanness even during the darkest hours of the war. In settings that were more daunting than the cliff alluded to in Shir Ha'Shirim, I glimpsed the face of kindness, the sound of delicate hope.

Following that glimmer of light, I came to understand more deeply why rabbinical commentators chose to link the trembling dove to the hour when Jewish people stood terrified at the Sea of Reeds. With the Egyptian army coming at them from behind and the watery depths looming in front, they, too, had given voice to both fear and awe.

While sheltered inside a steep cliff, the dove is invited out to show her visage. This invitation, I felt, was addressed to me as well as I entered more deeply into Chaya Leah's narrative. My own voice had to be heard in our conversations. It was not enough to seek the face of the past. I had to make room for its shadows in the present with unvarnished words.

In an email sent to me early in our work together, Chaya Leah described as follows the feelings of piecing together fear and hope. Speaking about the challenge of putting together a collection of photographs for this book, she wrote:

\footnotetext{
Yes, the pictures are beautiful ... and the masks are going to be removed, the makeup will be washed away and the nakedness will be exposed.
}

My goal was never simply to remove masks, since there was little that was presented to me that was made glossier than the reality had been. Nonetheless, it was a delicate challenge to enter a survivor's world where vulnerability still reigns supreme. 
Anchored by the words of Shir Ha'Shirim, I tried to tread delicately into Chaya Leah Walkin's world. All along, I had to remind myself that this is a history more complex than I can possibly fathom today. How can I come close and stay respectfully distant at the same time?

One answer to this query came from Rabbi Joseph Soloveitchik's masterful work entitled: And From There You Shall Seek. In this book, the Song of Songs is linked to a larger human quest for revelation. According to Rabbi Soloveitchik, this journey leads man to confront "realities unsought and often unwelcome." 24 One of those realities is the repeatedly failed or deferred communication that marks every chapter of Shir Ha'Shirim. Linking this process to the darkest historical events of the twentieth century, the author concludes that we have no choice but to live with what we cannot fully understand.

In an age captivated by theories and abstractions, I believe that our challenge remains the recovery of the complexities of lived experience. Rabbi Joseph Soloveitchik identified a key aspect of this challenge as follows:

Living experience of God, who transcends our human conceptions, confronts us as a philosophy-denying Other even as he addresses and makes himself available to us. ${ }^{25}$

In Chaya Leah's story, I also encountered such philosophy-denying otherness. I was privileged to be addressed by a woman who had faced the darkness of being a refugee and also stood her ground as a builder of Jewish community after the war. Recovering the fragments of Chaya Leah's story and placing them in a fuller context was, I now see, a truly sacred task for both of us.

24 Joseph B. Soloveitchik, And from There You Shall Seek (New York: KTAV Publishing House, 2009), 32.

25 Ibid., 42. 